\title{
THE PALESTINIAN IN DIASPORA
}

Research Notes

\author{
Julia Pitner \\ University of Kansas
}

Mid-American Review of Sociology, 1992, Vol XVI, No. 1: 61-91

\section{INTRODUCTION}

I spent the summer of 1990 in Palestine, living in East Jerusalem and studying Arabic. Although I have spent the last three years studying Middle Eastern history and politics, I had only done specific area projects on the subcommunity conflict in Lebanon and the political development of the Ba'ath party in Iraq. Consequently, I knew little of the current conflict or intifada that was happening in the Occupied Territories of Palestine although I knew the history of the area before I went. While I was there, I spent most of my time talking with Israelis and Palestinians about the current situation. I got quite an education. When I returned to the United States, I began reading about the Palestinian situation and discovered that although a great deal has been written about the Palestinians within the Occupied Territories, little has been written about the Palestinians living in Diaspora or as the Palestinians call it, the shatat [dispersal] or ghurbah [exile]. Although the Palestinians within the Occupied Territories continue to be the most visible because of the intifada, there are approximately four million living in Diaspora: in Syria - 265,221; in Lebanon - 288,176; in Jordan - 870,490; in the Gulf States - 790,000; and in other countries - 380,000 (UNRWA, 1988).

I decided to do a preliminary study of Palestinians in Diaspora. I talked with two types of Palestinians; those who are here studying but live in Arab countries and those that have made the United States their home by acquiring citizenship. Although the majority I talked with were K.U. students either currently studving

* or recently graduated, there were a few exceptions. I interviewed one student from Kansas State who was working on his Masters in Comparative Politics and I interviewed a Palestinian scholar who is considered "lcadership" because of his activities in the Palestinian National Council and his writing on the topic of Palestinians. I also interviewed a leading scholar in Palestine Studies to get an idea of how Palestinians in Diaspora are viewed by representative scholarship. She is also the faculty advisor to the KU chapter of the General Union of Palestine Students (GUPS). As a result she is frequently in contact with the KU Palestinian community.

There were several things I was interested in learning. First, I wanted to examine individual Palestinian views to compare them with what the Palcstinian 
leadership states in representing them. Also, I wanted to discover how the Palestinians outside of the Occupied Territories feel about a Palestinian nation, its leadership, and the leadership's goals. Second, I wanted to learn about the socialization and politicalization process of Palestinians because most Palestinians under thirty living in Diaspora have never seen Palestine let alone lived there. I was interested in how these young Palestinians have come to relate so strongly to a land they have never seen and how Palestinian history is passed on to them. Third, I wanted to examine two statements I have repeatedly seen in scholarly works on Palestinians: 1) That education is extremely important to the Palestinians because it helps them move up the social ladder; and 2) That Palestine as a nation did not exist until the expulsion in 1948 and that this expulsion created the Palestinian nation (nation as different from a state which requires territory). Finally, I wanted to find out how Palestinians vicw themselves in this Diaspora.

\section{PRE-1948 PALESTINE}

"There was no such thing as Palestinians.... It was not as though there was a Palestinian people in Palestine considering itself as a Palestinian people and we came and threw them out and took their country away from them. They did not exist." Golda Meir

Under the Ottoman Empire's rule from the 1300's until 1914, the region known as Palestine lived as did much of the Ottoman provinces. During this time, a majority of Ottoman provinces had a great deal of autonomy and in Palestine, villages and the areas surrounding those villages had their own local "governments". These were ruled by a Sheikh, who was the head of a prominent family in that particular area. Palestine was primarily an agricultural area although along the coast ports of trade developed. This remained basically the same until the mid-1800's when the Ottomans tried to instigate reforms to save their dying empire: " They attempted to solidify their rule by bringing the autonomous regions under direct control. They had a difficult time especially in Palestine because Ottoman leaders had to first undermine and then break the power of the local Sheikhs (Hirschfeld 1986, p. 269). Consequently, they were never able to fully bring Palestine under direct Ottoman rule. Palestine's autonomy led to a good deal of economic growth in the Arab sector between 1865 and 1914 as it developed links with the world economic system, especially the European economies. This growth was primarily brought about by the local Arabic speaking Muslim and Christian population (Gilbar 1986, p. 188).

Yet, there is great debate among scholars about the nature of the Palestinian nation before the 1948 War. Many say that there was no Palestinian nation until the dispersion in 1948. The argument against the existence of a Palestinian nation became even more prevalent after Jews began to immigrate in Palestinian nation became even more prevalent there are Israelis who say that while they are a people of the Book [the Torah and Bible], the Palestinians are a people they a pictionary, meaning they only exist in dictionaries. They assert that the Palestinians are Arabs first and last. Of those scholars who believe that the

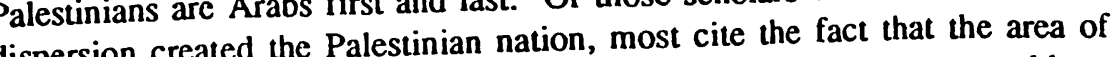
dispersion created the Palestinian nation, most cite the fact nation was able to Palestine had been ruled by so many foreign powe the to the Jewish Oleem form. Also, they credit the development of the area to the Palestine.

The revival of modem Palestine was due to both the great zeal of the Jewish pioneers and to the introduction of modern government and security measures mainly by the British after the First World War.... To be sure, the measulation of Palestine entered the country in the present century (Sharon 1975, p. 124).

Prior to Jewish immigration, the land was certainly not unpopulated. Palestine was an area filled with hundreds of small villages and a few large Palestine It is almost impossible to say how many people lived in this area during town. It is almentieth century but a Turkish census in 1914 counted the first decades of the twentieth century 725,000 . Of those counted in 1922 690,000 and the British census of 1922,725,000. Of those co-thirds who had 78 percent were Arab Muslims, 11 percent were Jewish (two-th 1991 pp. 7-8). arrived in the previous 40 years), and 10 percent Christian (Ccrer 191 pp. 7-8) "Palestinians weren't a bunch of immigrants that came over and said their own nation. They had their own heritage, their own tradis language" 1 ... before Jewish immigration began and certainly before the British Mandate came into affect.

While it is true that there was no state of Palestine with defined borders until the British Mandate after World War I, the same can not be argued for the Palestínian nation. A nation exists-so-long as a people-believe they are a nation. Other scholars as well as Palestinians argue that there was indeed a nation.

It is true that the experience of expulsion and also the experience of defeat in '67 solidified Palestinian sentiment. But all one has to do is go back and in there was clearly an expressed sense of national identity...we've got there was clearly part [of the argument] is that Palestinians are part of a broader Arab community and so it is true is 30 s whether 
Palestinians should be unified with Syria some way or in some kind of broader Arab entity. But that doesn't mean they didn't also have a sense of Palestinian identity...those two identities aren't mutually exclusive. ${ }^{2}$

With the issuance of the Balfour Declaration of 1917 and the heightened Jewish immigration into Palestine with the rise of Hitler, things began to change for the Palestinians. "The Palestinians like any other people under colonialism aspire to achieve their independence and self-determination. In their case, they had another conflict to deal with, which [was] European Jews escaping Europe, coming to their [Palestinians] homeland trying to claim it as their own." 3 Under British Mandate in the inter-war period, a grcat deal of conflict erupted between Palestinians and immigrating Jews. The Palestinians viewed this not as a religious struggle but as a struggle against European colonialism. Between 1922 and 1936, the Jewish population in Palcstine grew from 86,000 (11 percent of the total population) to 400,000 (30 percent). Most of this increase occurred between 1933 and 1936 (Flapan 1987, p. 18). Jewish immigrants, through the Jewish Agency, began to increase their land purchases in Palestine. Some of this land was sold to immigrants by Arabs living outside of Palestine at the time. "They never thought that by selling their land that they would be actually be forced to leave [and] that it would eventually leave them with no home." 4

Throughout this period, Palestinian leaders called on the British Mandate government to halt the immigration and land transfers and to set up a government based on proportional representation. The British refusal led to a three year "Arab Revolt" - general strike - against the British Mandate government in an effort to regain control of Palestine. In the wake of the general strike, the British government appointed the Peel Commission to investigate the cause of the Palestinian and Jewish grievances. The Commission proposed a partition of Palestine between a Jewish and Arab state with continued British control over specific areas. The Palestinian.leaders rejected this proposal because it meant giving up a part of their homeland and the forced evacuation of Palcstinians living in what would be the Jewish state. The Jews also rejected the Pcel proposal because they thought the land apportioned to them was too small.

During World War II while the Palestinian leaders were struggling among themselves for power, the Jews were building the apparatus of their "state". Although militias were deemed illegal by the British mandate government, the Jews succeeded in training and arming several military units; the Haganah, the Irgun, the Palmach, and the Stern Gang. After Germany's threat to the Middle East ended in 1942, these groups began to destroy communications and transportation lines in Palestine as well as other terrorist activities in an effort to expand their holdings, undermine British authority and convince the Palestinians to leave (Gerner 1991, pp. 41-43). By 1947, the British were convinced that they could no longer resolve the problems in Palestine and turned it over to the newly created United Nations.

The U.N. created an eleven member committee to examine the problem and recommend possible solutions. They presented two proposals: the first called for a partition of Palestine into two separate states, one Jewish and one Palestinian; the other called for a single federal state with autonomous Jewish and Palestinian areas; and both proposals called for an expedient end to the British mandate. The Partition Plan had the support of the majority of the committee and was thus proposed to the U.N. General Assembly. The Arab League, created in 1945, and the Arab Higher Committee, which represented the Palestinians in the U.N., rejected the proposal as an illegal and illegitimate division of Palestine (Gerner 1991, p. 44). Instead they called for a secular democratic state in which all citizens would have equal rights. Although the Jews were not happy with the Partition Plan, they supported it and lobbied for its adoption in the General Assembly. They believed that they could increase the size of their state with time and were therefore willing to accept the Partition Plan. On November 29, 1947, the United Nations adopted Resolution 181 which called for the partition of Palestine into two states.

With the release of Israeli government documents, there is now evidence that the Jewish leadership in Palestine sought to undermine any type of compromise that would allow for a separate Palestinian state (Flapan 1987, pp. 57-79). Although the Palestinians in Palestine tried desperately to reach some type of compromise with the Jewish leadership, the violence and turmoil created by the Jewish military units only increased during the rest of 1947.

A couple of weeks before the creation of the state of Israel there was a British truck that was attacked by the Haganah, which [was] the Jewish defense force in those days. It exploded right on the front of our house and the roof collapsed and the family had to leave. "So we went to our grandparent's house and my father was planning to go back and fix the house so we could go back and before he could go back there was a border and a new state and he wasn't allowed to go back. We lost everything. We basically left in our pajamas. 5

Until the formal declaration of Jewish statehood on May 15, 1948 the Jewish military units tried to expand the 'borders' of the U.N. Jewish state with terrorism and military action. The exodus of Palestinians, both forced and voluntary, began with the publication of the UN Partition Plan in November 1947 and continued even after the armistice was signed in the summer of 1949. 
"The Palestinians were really unable to defend themselves. Their land had been taken over, first by the United Nations Resolution which gave the [Jews] fifty percent of the land; then by war, they got 70 percent of the land." 6 They were unprepared for the systematic takeover of Palestine which the Jewish leadership had planned since before the end of World War II.

The Arab States declared war on Israel hours after the formal declaration of statehood. However, it is not the defeat of the Arab armies or the war itself that the Palestinians recall when asked about 1948. They simply explain what happened to them with one name - Deir Yassin. What happened in Deir Yassin has come to symbolize Palestinian pain and terror, and the unscrupulous way in which they were treated. The village of Deir Yassin was located in a largely Jewish area near Jerusalem and had signed a non-aggression pact with its Jewish neighbors in 1942. Because of this, they had not asked for protection from the Arab armies when fighting broke out. Yet, on April 9, 1948, the Irgun and Stern Gang (LEHI) carried out the systematic slaughter of 245 villagers - almost the entire population. When Palestinians heard, they became frightened that they would also be massacred.

How shocked people were, basically they were not educated and they did not know that something with this magnitude could happen. This was a highly organized step by step move to take over the land. People were shocked and scared and astonished. 7

There were also forced evictions, the most famous of which was the evacuation of Lydda. After the village leaders surrendered to Israeli forces for lack of food, water, and other necessities, the IDF (Israeli Defense Force) gathered everyone in the village and marched them toward the next nearest village that was being held by an Arab army. Between 600,000 and 700,000 Palestinians were evicted or fled from the areas that were allocated to the Jewish state under the Partition Plan or occupied by Jewish forces during the war and later integrated into Israel. During and after the exodus every effort was made to prevent their return - from razing villages to the enactment of laws (Flapan 1987 pp. 81-118).

\section{DISPERSION AND DIASPORA}

"Sometimes I feel like the man on the cross; one hand stretched to the east, one hand stretched to the west. When I'm there, I miss here. When I'm here, I miss there." -Dr. Jamal Nassar
1948 to 1967 The Politicalization of the Diaspora

After the War of 1948, Palestinians were in a state of shock. Those who became refugees from what had become the state of Israel, fled to the East Bank of Jordan (now the West Bank), Gaza which was part of Egypt, Lebanon and Syria. Their main concern became that of survival. They had lost everything and were forced to start over. Many were living in refugee camps, others went to live with family. At first, the majority believed that they would only be refugees for a few months at worst, until they were allowed to return to their homes. When it became clear that they were not allowed to return they needed to find employment, so those who had skills began to disperse. Those whose primary livelihood had been agriculture found nowhere to go except the refugee camps set up by the United Nations Relief and Works Agency in the Near East. These Palestinians took what work they could and began to save money to send at least one child to college in order to better their situation.

A way out of the camps is through education...they have to be so well educated that the Arab World or the United States or Europe will hire them. So the typical pattern is that you send one child to school first, to university, then they go abroad and that's the money for the next child to go to school. And they realize that's the only way they can survive is to go outside to work. 8

Education was used as a way to find some security. With an education, it was possible to find jobs elsewhere in the Arab world, Europe, South America and the United States. Those who had an education at the end of the war were sent out to find work and then to send for their family if possible or just to send money home.

In 1956, my father was 16 years old and because of the economic situation for Palestinians after the 1948 war, they were in need of money, my giranđfather semt him to Venezuela ist order to.work.9.....

A social network began to form whereby the "intelligentsia" immigrated first then sent for family and friends who then in turn did the same. Communities of Palestinians began forming in the Diaspora (Ghabra 1987). This network became very important not only in finding jobs but in education as well. For example, each of the Palestinians interviewed stated they came to this area because of a brother, cousin, or friend who was here or had been here for schooling. So that although the role of education changed later in the Diaspora, the importance of the network has not. 
Several important things occurred during this time that gave new direction to the Palestinian Diaspora. After more communities were formed and grew larger, a politicalization process began. The Palestinian family grew to include those outside the bloodline. This was a new occurance in the Palestinian social structure. Palestinians began to become more unified in their struggle outside Palestine. The immediate family became the holder and teacher of Palestinian history and identity. This is why when asked, a Palestinian will tell you s/he is from a specific village in Palestine even though they may have never seen it themselves. It is passed down from generation to generation, like the land itself was before the dispersion, as an inheritance.

I grew up knowing I was Palestinian even though I was born in Kuwait. My parents taught me since I was a little boy, that, here is a beautiful country but it is not home. The Israelis took your land and a person with no land has no dignity. But through education you can get the land back. They made sure I knew what was going on around me and they made sure I knew that this [Palestine] was my homeland and you shouldn't be ashamed of it. I am proud to be Palestinian. 10

Another reason their history and their Palestinian nationality became so important was that the countries they fled to, with the exception of Jordan, encouraged the Palestinians to maintain their distinctive identity. The Arab states did this for economic, political and social reasons. To grant them citizenship was tantamount to conceding permanent Arab loss of Palestine. They were also afraid that accepting so many Palestinians as citizens would destabilize their political systems and thus made it very difficult if not impossible for Palestinians to apply for citizenship. This was especially true in Lebanon where the delicate balance of the sectarian government would have been greatly stained. Furthermore, a majority of Palestinians were reluctant to adopt a

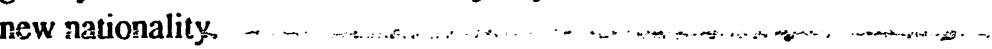

One of the other major developments during this time was the creation of the Palestine Liberation Organization in 1964. The creation was the Arab League's response to the anger and exasperation of the Palestinians who were realizing that they were doing nothing to liberate Palestine. Originally, the PLO was created to speak on behalf of the liberation of Palestine but not to do any actual fighting. In 1965 the Fateh was created separately by Palestinians as a guerilla movement. Since it was not part of the PLO and not under the control of any Arab government it greatly worried the members of the Arab League. They decided to have the Fateh's leader, Yasser Arafat, arrested in Syria hoping that this would cause his followers to disband. The Palestinians, for the most part, realized that the PLO under the control of the Arab League would do no more than the Arab states previously had. This fact was driven home during the 1967 War. "During the war there was a sense of excitement. We had been used to a lot of Arab rhetoric that [said], 'it will be no problem to liberate Palestine', that the Arabs will be able to win. In a matter of a day or two, we realized that the rhetoric was nonsense basically. After the war a major disappointment set in, a major sense of frustration set in and we decided that if you need to bring about justice, you need to do it yourself and not depend on neighboring Arabs or anyone else."11

This is exactly what the Palestinians did after the 1967 war. After they lost the rest of Palestine to Israeli occupation, the Palestinians in diaspora took control of the PLO.

The Palestinian people began to support their own commander groups which in time took over the Palestine Liberation Organization. The PLO up to that point was dominated by the Arab governments and [the Palestinians] began to work on their own to struggle for, to liberate their homeland through guerilla warfare. 12

There was at this time a whole new Diaspora. Over 400,000 were displaced from their homes, about half of them for the second time in twenty years (Peretz 1970, pp. 41-45). Now there were two types of Palestinians; those in diaspora and those under occupation. This exacerbated their frustration and anger and the Palestinians in diaspora now believed that they must take control of the war to liberate Palestine. Yassar Arafat became the head of the PLO and wrested its control away from the Arab governments. Thus began a new phase in the politicalization of Palestinians both inside and outside the new Occupied Territories.

The PLO started really in 1967 because the Palestinians realized that to keep their identity, they have to rely on Palestinian leadership that will take Palestinian problems, aspirations, and hopes into account. 13

\section{Between 1967 and 1987}

After the war, many Palestinians who had been studying and working abroad but had lived with their families in the West Bank and Gaza, were not allowed to return home. The Israeli government stated that if they were not in the country at the time, they were not citizens and therefore, had no right of return. Many Palestinians living abroad thus became, as the foreign governments called them, of questionable origin. Families became even more divided and scattered. 
I wasn't allowed to retum there [Palestine] until I became a U.S. citizen in 1977. Because when I left there in 1966, the West Bank was not under Israel. The Israelis in essence, took away my right to residency in my own home town and when I go back now I am detained at the Arab section, and detained there for questioning for anywhere from 20 minutes to 4 hours. 14

Families were also divided between the West Bank and the rest of Jordan. In 1967 the Israelis captured what was the East Bank belonging to Jordan. A new border was established and the Israelis were then in control of visitation rights between Palestinian family members who now had to cross a border that had not existed before. This created a great deal of anger and frustration as they tried to deal with this new occupying force and the disappointment in the Arab governments that were supposed to help them. These frustrations built the base for the development of a more politicized and active Palestinian Diaspora.

Although some political organizations existed before the 1967 war, institution building began in ernest after 1967. As was already mentioned, the PLO was created in 1964 but was taken over by Palestinian leadership after the 1967 war. The Palestine National Council (PNC) was created at the same time to act as the PLO's parliament. Since 1969, its members have represented roughly the proportional strength of their party in their communities. Also represented are the social and popular organizations (Brand 1988, pp. 12-21). The PLO and PNC played a very active albeit militant role from 1967 until the mid 1980s. It began to be a very important part of the Palestinian Diaspora. One Palestinian summed up the feelings of the Diaspora for the PLO and PNC:

They have given the Palestinian people a sense of national identity. They have let the world know of the plight of the Palestinians, the problems that the Palestinians have faced and they have attempted to struggle and they have sacrificed in order to bring about an end to the injustices committed agairst the falostianians. 15

The PLO did not have an easy time within the Arab World. In 1970 the Jordanian and Syrian governments expelled the PLO and a great many Palestinians. They feared the growing power of the PLO among its citizenry as well as among Palestinians. The PLO found haven in Lebanon with the help of the Arab League. They were able to remain there because of Lebanon's own internal distractions until 1982 when the Israeli army invaded Lebanon to destroy the PLO. In an agreement between the PLO, the United States, and Israel, the PLO left Lebanon and moved its headquarters to Tunisia, and then to Algeria. Having to leave the immediate area of their conflict caused the PLO to lose some of the power they formerly had because it was difficult to carry on the struggle from across the Mediterranean Sea. The PLO was forced to rethink its strategy and instead began to focus on a diplomatic solution to the Palestinian problcm. However, it did not lose support from the Palestinian population. When asked if they considered the PLO and the PNC to be their legitimate and representative govermment, they all answered with an unequivocal, yes.

When we talk about the PLO we're talking about the Palestinian state. The PLO is a state of mind. The PLO is the combination of our aspirations to have a homeland. When you talk about the PLO, you talk about Parliament, you talk about governments, the executive committee, you talk about the Army, you talk about social welfare committees, you talk about all the things you find in an independent state. We also have a constitution, the constitution of the independent Palestinian state, which calls for a democracy. When the time comes when we have an independent state, we will no longer have the PLO. The PLO will become the state because the functions of an independent state are now performed by the PLO because there is no state yet. 16

Another important organization in the Diaspora is the General Union of Palestine Students (GUPS). Although having been formed in 1959, it became more active after the 1967 war. With the encouragement and help of the PLO, GUPS began to increase the number of Unions and memberships at universities throughout the world. In 1972, GUPS formed a branch at the University of Kansas and it still exists today. During the course of interviewing, when asked about community, almost all referred to GUPS as their local community. In general, it has remained the most influential mass organizations in the politicalization of young Palestinians and is used as a vehicle for education of the plight of Palestinians throughout the world.

The PLO and GUPS, along with many other organizations, grew after 1967 and solidified the Palestinian identity, nationality, and thus the struggle of Palesinians in Diaspora. Bectuse of this, thie Diaspora community became very visible. Also the nature of the importance of education changed during this time. It was no longer a mater of mere survival but became something much more important, a symbol, a possession, and a war.

For a long time Palestinians prided themselves on how educated they are and they are very educated. If you take any third world country statistics, Palestinians are among the most educated if not the most educated.... It is paying off, for example, the delegation to the Madrid Conference. They were highly educated, they all spoke and understood english. None of them needed any assistance with translating or anything. If you're educated you 


\section{Mid-American Review of Sociology}

are definitely better equipped to advocate any cause you believe in and for me that is the Palestinian cause. 17

The Palestinians have lost their land, have lost their homes, have lost their identity and so on. And therefore, Palestinians have come in time to emphasize education because that is one thing no one can take away from a person. If I put my money into a building, the building can be razed in a war or it can be confiscated. But, if I put it into educating my son, no one can take that education away from [him]. So, to the Palestinians, education became paramount just like the case for any people in Diaspora. 18

Education is a form of Jihad. You're not putting yourself in danger physically but when you educate people and tell them what's the truth and you defend your word and the facts and try to deliver it to people and not mislead them, its a way of Jihad in our religion. When you physically go to war you are physically protecting your country, your borders, your people. In Jihad by education we are protecting them so they won't do anymore mistakes in the future. Making them aware of what's going on so that basically you're mentally protecting the future. 19

Education is important to the maintenance of Palestinian identity and nationalism as well as to the community. They are preparing not only for the immediate future but also for the time when they will have their own state. From 1967 through 1987, education continued in importance as it had after 1948, but for different reasons, and education is becoming even more important today with the challenges facing Palestinians in the international community.

\section{THE INTIFADA AND BEYOND}

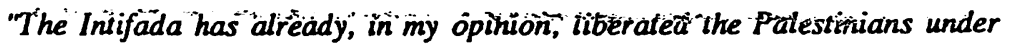
occupation from their fears of the occupier." -Dr. Jamal Nassar

If 1948 was the first turning point in Palestinian history, and the 1967 War the second, the intifada is the third and maybe the most important. After 1967, the Palestinian in Diaspora was very visible in fighting for the Palestinian cause. On December 9, 1987, world attention focused on the Palestinian "inside". Many scholars assert that the intifada gave new life to the PLO and new hope to the Palestinian Diaspora. The PLO, after having moved out of the immediate area of the struggle in 1984, changed the nature of their struggle to focus on a diplomatic struggle. However, this had been just as frustrating because the yield was minimal. Although they had received recognition as the sole legitimate representative of the Palestinian people from most of the world and the U.N. especially after the declaration of independence in 1987, achievement of some type of settlement with the Israelis had not been forthcoming. In this respect, the intifada breathed new life into those efforts, especially when the world watched Israel's brutal treatment of the protestors on their televisions.

People are fed up with the occupation, fed up with the way they have been treated by the Israelis and nobody else its doing anything about it. So, they took it into their own hands. They are representing me in this struggle. I can't do anything about it outside because I am an individual and my people, as the PLO and PNC, are trying to do something but nobody is listening to them and everybody is ignoring them, so why not have the people inside voice their own opinions, give their own statements and have the people outside who say that there is nothing going on in Israel, that Israel is doing nothing wrong, realize that yes, there is something going on, why are these people upset. I am glad to see it but I feel bad that nothing is being done, people are getting killed every day....20

The intifada, while it has helped the visibility of the Palestinian people and nation, has also caused debate among the Palestinian community in Diaspora. The debate revolves around the issue of whether they are a part of this movement or merely bystanders wanting to be a part of this monumental struggle of their nation.

The intifada, as much as we hate to admit it, is the intifada of the people of the inside, the 2 million on the inside are taking care of it and we have not been doing much to help them. We having been talking in support of the intifada, we have been chipping in some money, but basically, we haven't done our share so that we can claim that this is also the intifada of the 5 million. The intifada is the best thing that happened to Palestinians for years and years and we realize how much the intifada has done for the Palestinian cause and for Palestinian rights. Around the world, as Palestinians outside, we cannot claim that we are part of it, even though we can claim we support it. 21

Every single Palestinian would like to contribute more that's for sure, but the issue of inside/outside does not exist. Five years before the intifada the outside was suffering more than the inside but we did not feel that we are suffering they are not. We are all one nation, all one people, the separation is just because of the occupation. 22 
There is no question that the intifada has given the Palestinian cause world recognition and attention. Palestinians in Diaspora all agree on one point:

...[t]he intifada has risen the Palestinians to new heights and it is the intifada that took the Palestinians to the Madrid Peace Conference. Without the intifada, the peace conference would have been attempted like other peace conferences in the past, without the Palestinians. Given the intifada, there was no altemative but to include the Palestinians in any future peace negotiations. 23

However, there is concern among Palestinians in Diaspora about the nature and evolution of these talks.

We should have been represented in a different manner, in the sense that, Palestinians who are abroad are not represented. They [the delegates] are all from the West Bank. Palestinians in Jerusalem are not represented, Palestinians in Lebanon, in the U.S. and elsewhere are not represented and we should have had the choice to elect our representatives like any other people rather than have those in any way imposed or superimposed by some other power, especially the enemy itself, Israel.... [By] putting conditions on Palestinian representation will weaken the results of the conference and any outcome it may come up with. [This] legitimizes those who oppose the conference. 24

Palestinians in Diaspora face a difficult dilemma, especially since the Gulf War. Their situation in the Middle East is tenuous. It was becoming difficult for Palestinians in Diaspora to find jobs anyway because of the slump in the economies of oil producing countries. Now, they are also being expelled from Kuwiait, Saudi-Asabia, and Egypt because of the stand that Arafat took during the war. Palestinians are especially frustrated by this. They feel there was a misunderstanding about what Arafat's intentions were and that the United States did much to foster this misperception.

The objective of the American media was to deliberately align the Palestinians, specifically the PLO with the Iraqis so that when everything is done and over with, the PLO will have a weaker position coming into the negotiations [peace conference]. The Executive Committee of the PLO issued a communique on August 5 , three days after the Iraqi invasion, calling upon the Iraqis to respect international law and to address the issues through negotiation and discussion but this was never mentioned. There was no place for someone to be neutral, the Americans said if you are not with us you are against us. The PLO was working for a peaceful settlement.... The PLO was against the U.S. invasion of Iraq and not for the Iraqi invasion of Kuwait. This was not understood. 25

Palestinians are both hopeful and afraid of the outcome of the peace conference. Although the PLO has not been able to be a part of the negotiations, they assert that the PLO has been consulted on everything and therefore is very much a part of the talks. The war has shown them how changing perceptions and political objectives can change their status almost overnight. However, they are afraid that if nothing comes of the peace talks that the Palestinian movement itself will have to change and they are not sure what that change will be. Some believe that radical groups such as the Hamas and the Islamic Jihad will gain in power and take over the movement thereby changing it to a religious Islamic struggle. This in turn, they believe will escalate the violence not only in the Occupied Territories but around the world. "They will have nothing to lose, if the peace conference doesn't work, we have lost everything already." 26 All that is left to them is a hope that some day they will be able to return to as a nation to an independent Palestinian state.

...[they] lived in a state of exile. Nowhere were [they] citizens of the lands of their birth; everywhere were they governed by discriminatory laws that determined their entire lives. In a few places [they] led tolerable even comfortable lives, but in others they were forced to live in ghettos; in others they were not allowed to live at all: and everywhere their existence was extremely precarious, entirely dependent on the whims of despots and the vagaries of fleeting public opinion (Sober 1990, p. 9).

It is somewhat ironic that what was once meant to describe the Jews in Diaspora can, forty-three years after the creation of the State of Israel, be said about the Palestiniâns. "Bư "wè 've seễ Diaspora] have stayed together not because of a big dream or trying to achicve a Bible prophecy by going back there but because we are Palestinian, part of Palestinc." 27

\section{THE INTERVIEWS}

This paper is based on interviews I did with Palestinians in the Lawrence and Kansas City area. In all, I conducted seven interviews although I spoke with eleven Palestinians and one non-Palestinian scholar. The interviews were closedended, meaning there were set questions and specific information I wanted to 
discover. Each interview lasted approximately one hour; the longest was one and a half hours, the shortest 40 minutes. Of the Palestinians I interviewed, one had grown up in Dhahran, Saudi Arabia, one in Riyadh, Saudi Arabia, one in Kuwait City, Kuwait, two in Beirut, Lebanon, one in Damascus, Syria, one in Amman, Jordan, one in Venezuela until he was eleven when his mother moved back to the West Bank, two who had grown up in the West Bank and the last was from Nazareth, Isracl (See Appendix II for interview questions).

Although each had come from different environments, they had many commonalities. I began to realize through the course of the interviews how very important the family is to the politicalization and thus the continuation of the Palestinian nation. When asked when they first realized they were Palestinian, each expressed the same idea. One respondent summed it up by saying:

As far back as I remember when I was a little baby. I always heard the stories about how our family became refugees, how we lost our home, we lost our business, we lost everything we had. 28

Another told of a children's book called Al-Byte al-Filistinya (the House of the Palestinian) that his father used to read to him and his siblings as a bed time story. It told the story of the 1948 exodus and

it starts with, 'a man has a house, the cat has a house, the dog has a house it starts with, a mas so and so has a house. The Palestinian had a house but he doesn't have a house right now'. This is my first recollection of being Palestinian. Then when my brothers were a little older, he read them that. My uncle reads it to his son. It's become like a tradition. 29

The mental connection to Palestine as a geographic location instead of an ideal, seems to be very important to Palestinians in Diaspora. In fact, in answer to the first question' "Wherte are you' fiom?" each añswered with the name of a to the first question "Wherte are you riom? been to the village they named. In fact after one interview the respondent asked been to the village they named. In fact after one interview the respondent asked if he could see the pictures 1 had me about what it was like, and what was going who had never been there asked me about what it was like, and what was going on there. Although they had nevathers as their home; their right of heritage. The village of their fathers and grandfathers as their home; their right of heritage. The Palestinian society and family structure is strongly paternal. Therefore if the father is Palestinian and the mother is not, the child is still considered Palestinian. They trace their heritage and land rights through the father's family. The paternal family has become their link with their past, present and future. This also includes what may be called the extended family or "community", although the word community posed some problems during the course of the interviews.

I had a difficult time getting interviews after the first one. After the conclusion of the first interview, I asked the respondent if he knew of anyone else who would be interested in talking to me. He said he did but that he wanted to call them first before he gave me their names. I thought that would be alright but asked him not to disclose any information outside of the nature of my project. I didn't hear from him for a couple of days so I called and he told me that everyone was busy but gave me one name; the head of the KU General Union of Palestine Students. He would give me no other names, they were either too busy or "did not know enough". I could not talk to them myself.

After discussing the problem with several people, I began to think that there may have been some community "rule" which prohibited its members from identifying them without prior permission or the okay from 'leadership'. I had decided that if I was unable to talk to the second respondent, I would ask the first respondent whether I was putting him in an awkward position or if he was just too busy to call them but didn't want to tell me. Fortunately, I was able to get an interview with the second respondent. After that interview, he gave me several names and phone numbers and in fact, he arranged an interview for me with the President of the Kansas State GUPS.

During the course of the interviews about half denied being part of a local Palestinian community. However, at the same time, I observed a fairly active community. This was especially evident in sixth interview. While I was interviewing we were interrupted several times by other Palestinians calling or stopping by, so that toward the end of the interview I was interviewing four Palestinians, two that had come by and brought dinner. I began to lend some credence to the hypothesis of a community "rule" of non-disclosure. After the interviews were complete, I returned to the second respondent (the "leader") and asked him once again about being part of a local Palestinian community. Again he said he wasn't part of a Palestinian community, but then I told him that I had

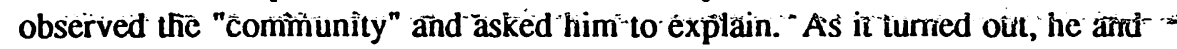
probably several others had misunderstood what I meant by community. He thought I was referring to the formal meaning of community; families, collective living, etc. When I explained what I had originally meant by community, he then agreed that there was one.

Some of the symbolism I used to experiment with the phenomenological aspects of the interviewing environment also had some unexpected results. To one of the interviews I wore a red khafiya, which is often worn in the Occupied Territories as a show of support for the intifada. The interview was held at the respondent's house and his walls were covered with posters; a Palestinian flag and one that said Free Palestine. At the end of the interview he asked me why I 
had a red khafiya instead of the traditional black and white one. He did not know the symbol which I had hoped would have some effect on facilitating the interview. When I explained its significance he said, "We only know what's going on 'inside' by what we see on television or read in the paper, which in this country isn't much". I found this to be generally true unless they had family on the "inside". After another interview I was explaining how I got interested in this project and I said I had been in the West Bank. He asked me to tell him what it was like, and what the Palestinians in the Occupied Territories were feeling and experiencing.

Other interviews went much better. The first interview was held at my house so that I could keep the Arab tradition of hospitality. I served my guest a cold drink while we made small talk, followed by a snack, then I served him Arabic coffee as we began our interview. I asked the first question "Where are you from?" in arabic. I think he felt comfortable because he then began to express himself with the hostility and bitterness he felt towards his situation. Most of the other interviewees tended to be more diplomatic in their answers, especially in answering question \#16 which examines Palestinian attitudes toward scholarship that asserts there was no Palestinian nation until the dispersion in 1948. Of all the questions this one prompted the most hostility in the majority of those I interviewed.

In another interview where the respondent knew nothing except the nature of my project, the interview was very stiff. This was also partly due to the environment in which the interview took place. We met in one of the alcoves in the cafeteria and it was a fairly formal setting. I felt that I was getting the "party" line because he was telling me nothing new. So about half-way through I turned off the tape recorder under the pretense of having to start the other side. I asked him about his classes and he asked me about mine. I told him that I would be graduating in May, "Inshallah", which in arabic means God willing. His face lit up and he asked me where I had learned that and I told him.

it opeiresta whole new line of questioning because as.it tumed out he was a devote Muslim and closely identified with this expression. Although the use of Arabic had a purpose, the choice of this word was random. However, because of this chance remark, I discovered that although he claimed the Palestinian identity first, he actually identified more closely with the Islamic movement. This was explicitly expressed when I asked him about the peace conference:

As for the conference, it just doesn't seem there will be a positive outcome where both sides will be pleased...I think the Palestinian people will continue fighting for their nation, and the Israelis will continue holding on. But eventually, I feel there will be a Palestine later on. The nation will be liberated and the Israelis will be expelled. There have been several predictions in the Qur an... and one of the predictions is that the Muslims will get together and liberate Palestine. I look at it from that stand point....30

The interesting thing about this is that many Palestinians are Christian and as such do not fit very well into this scenario. He was also very adamant that it was not Pan-Arabism that he was speaking of but only Muslim countries. He was the only Palestinian to express this view. Since he was also the youngest, I began to wonder if this might be a trend within the new Palestinian generation. After doing further checking, I discovered that what he was saying was the party line of the Hamas. The Hamas is an Islamic fundamentalist party that has been operating within the Occupied Territories for some time and they are growing in power through the younger generation as well as those who have given up hope of any other solution.

The peace conference was not the only division of opinion within the Palestinians in Diaspora. They are also in disagreement about PLO decisions and policy. However, when I would state what other respondent's opinions had been, all of them stated that diverse opinions are necessary for a democracy to function. I am not completely convinced that they meant this. The majority of the respondents paused and looked away when they made this statement. I got the impression that they were trying to decide whether or not this was good or whether it is better to stick together and thus appear unified.

At first I was concemed that my bias in favor of the Palestinian cause would harm the interviewing process. Although I never expressed this opinion outright before or during the interview, I found that speaking of my trip to the West Bank tended to facilitate better communication. We then had a connection and for most a topic on which to trade information. It turned out to be a much better facilitator than the use of Arabic, symbolism or differing terminology. I think this was the case because of their strong psychological ties with Palestine and all that it means to them. I think it also helped to give me credibility. The only time this did not seem to be a factior was in the interview I did in a restaurant. There were so many distractions and interruptions that it was difficult to build any type of rapport. The respondent had also just finished a radio talk show in which he debated the issues with an Israeli student so that he treated my interview as just another debate.

One of the most important things I discovered through the interviewing process is that the Palestinian in Diaspora is a political being. Everything is put into the context of politics and political expression. When I asked what they do when they get together, the social activities were far fewer than the political ones. Even within the family unit, politicalization is very important. Perhaps 
Mid-American Review of Sociology

this is because their history, as well as their present and immediate future revolves around politics and political understanding.

\section{DISCUSSION}

are done differently with this project. First I made an assumption that my Palestinian friend would help me to get intervicws with other Palestinians. What the reasons for his reluctance were I intervicws with other Palesthing am not sure,

possibilities.

Second, I would have conducted all the interviews at the was done in a respondents or at my house. The fourth interview 1 conducted was interview restaurant and there were too many distractions and in chance to build the kind of did not flow very smoothly and I did not feel I had a chance to bue alcoves at the rapport I would have liked. I did another intervivacy and no internuptions the Kansas Union but even though we had total privacy and very stiff during the atmosphere was very cold and sterile. The respondents, the atmosphere was conducive to a more informal, conversational interview and on the whole the interviews went much better. I did one telephone interview which went fairly well even though I was nervous. It was harder to do than the others because there was no personal connection.

Third, I made an assumption about word choice especially with the Thmity question. Because I was getting a response that was the direct comm second opposite of the one anticipated I had choice "community" had confused him as interview why this was so. The word choice "com I had in mind was a political I am sure it did other respondents. The meaning word "nation". I made the science meaning. The same was true for the word assumption that everyone knew the difference between a nation and a state. The majority of respondents did not make the uistinction between nolitical vocabulary I had to explain what I meant. I was so worried about that I had not realized the concerning the West Bank, Gaza and the intifada that

political science terminology had crept into the questions.

Fourth, in the interviewing procss isself the time, I was concerned that if I got too far away from the quest get bored. I realized after listening to the tapes again, that there were a few interesting possibilities I could have explored but didn't. I think that my interviews may have been too structured. However, for the most part, I think that the interviews flowed fairly well and I am happy with the information.
Finally, I would have liked to have done more interviews. Interview \#5 inspired another question about the politicalization of younger Palestinians. After interviewing him, I began to wonder if other Palestinians were turning toward Islam because of their disillusionment with diplomacy. I would have liked to follow this up with just a few cursory interviews on this question alone. In the 6th interview, I ended up talking with four Palestinians at the same time and the interview turned into a round table discussion. I would have liked to have talked to them individually after that interview to see if they answered in the same manner. One of those present was particularly domineering and I felt that he might have swayed a few answers.

\section{CONCLUSIONS}

During the course of the interviews I learned quite a few things that I didn't realize and had never read before. One of the most important things is that Palestinians are political beings. Perhaps this is due to the very political nature of their history. Nowhere have I encountered a history that is so open to interpretation and revision as that of Palestinian and Israeli history. It is argued back and forth as if it were some type of theory and not events that had already occurred. This is the most fascinating and frustrating aspect of their history. The Palestinians psychological attachment to the land is very strong and everything is identified with the land.

For many years the Arab states have boasted of their financial support of the PLO. I discovered and verified that the money actually comes from the Palestinians working in the host Arab country. Five percent is taken off the top of every Palestinian paycheck by the government and then forwarded to the PLO in that country's name. This often makes the Palestinian workers very upset, even though they support the PLO. They feel that the Arab governments should be giving their own money and not that of the Palestinians.

Locally, the Palestinians are a fairly tight knit group. The GUPS at KU has not been very active since the beginning of the Guif War because of fear and frustration. This has caused a small break down of communication between the older students and those just coming to $\mathrm{KU}$. This may have an effect on the politicalization process that occurs with the younger students. They may not become as active or visible as the GUPS once was. This may eventually weaken the younger Palestinians support of the movement itself for students in the United States.

Through the coursc of this project I discovered some interesting facts and thoughts for future study. The one I have already mentioned, is the rise of the Islamic movement within the Occupied Territories. However, the idea that I find most intriguing is one that occurred in an intervicw with a Palestinian from the 
West Bank. He was telling me of his experience in an detention camp. He had been given a year sentence there for being suspected of throwing stones. He said that he had learned more about Palestinian history and politics in the camp than he had ever leamed anywhere else. The Universities, secondary and sometimes primary schools in the Occupied Territories are often closed for months and sometimes for years at a time. When they are open, these schools are not allowed to even mention the word Palestine or Palestinian let alone teach about it. Consequently, no politicalization occurs in the school system. However, the Israelis continue to imprison Palestinians convicted of intifada related crimes (usually scholars and activists) together in the same camps. This Palestinian told me that they hold classes and meetings about Palestinian history and the meaning of the intifada. Therefore it would be very interesting to do research on the politicalization and social structures of Palestinians within these detention camps since they are often there for long periods of time.

\section{ENDNOTES}

1. Interview \#1.

2. Interview \#7 with Dr. Deborah Gerner, Associate Professor at the University of Kansas.

3. Interview \#3 with Dr. Jamal Nassar, Professor of Political Science, University of Illinois in Normal Il.

4. Interview \#4 Palestinian student at Kansas State University.

5. Interview \#3 Dr. Jamal Nassar.

6. Interview \#2.

7. Interview \#4.

8. Interview \#7 Dr. Gerner.

9. Interview \#6 Palestinian student who has lived in the West Bank since he was eleven when he moved there with his mother (also a Palestinian) from Venezucla where his father still works. Kuwait.

11. Interview \#3 Dr. Jamal Nassar.

12. ibid.

13. Interview \#4.

14. Interview \#3.

15. Interview \#3.

16. Interview \#4.

17. Interview \#4.

18. Interview \#3.

19. Interview \#6.

20. Interview \#1.

21. Interview \#4.

22. Interview \#6 a Palestinian student at K.U. who is originally from the West

23. Interview \#3.

24. ibid.

25. Interview \#4.

26. Interview \#1.

27. Interview \#2.

28. Interview with Dr. Nassar.

29. Intervicw \#2. 
30. Interview \#5.

\section{REFERENCES}

Brand, Laurie A. 1988. Palestinians in the Arab World. New York: Columbia University Press.

Curtis, Michael, Joseph Neyer, Chaim L. Waxman and Allen Pollack, eds. People, History, Politics. New Jersey 1975. The Pale Transaction Books.

Epp, Frank H. 1976. The Palestinians: Portrait of a People in Conflict. Scottdale, Pennsylvania: Herald Press.

Gerner, Deborah. 1991. One Land, Two Peoples: The Conflict Over Palestine. Boulder: Westview Press.

Ghabra, Shafeeq. 1987. Palestinians in Kuwait: The Family and the Politics of Survival. Westview Special Studies on the Middle East.

Otroman Palestine 1800-1914: Siudies in Economic and Gilbar, Gad ed. 1990. Ottoman Palestine Social History. Leiden: E.J. Brill. The Ordeal of the Palestinians 1917-

Gilmour, David. 1980. Dispossessed: The 1980. London: Sidgwick \& Jackson.

Harkabi, Yehoshafat. 1979. The London: Valentine Mitchell.

Inad, Abu. 1981. My Home, My Land: Struggle. New York: Times Books.

Flores, Alexander. 1984. The Palestinians in the Israeli-Arab Conflict. Socied Conditions and Political Attitudes of the Palestitum der Deutschen Gesellschaft Territories and the Diaspora.

fur-Auswartige Politic e.V.

in the Late Ottoman Period: Politica!, Kushner, David, ed. 1986. Palestine in the Lasalem: Yad Izhak Ben-Zvi. Social and Economic Transformation. Jerusalem: Yadestinian Nationalism. New Muslih, Mohammad. 1988. The Origins York: Columbia University Press. 1990 Intifada: Palestine at the Nassar, Jamal and Roger Heacock, eds. 1990. Intifada. Palestine at the Crossroads. New York: Praeger.

Nazzal, Nafez. 1978. The Palestinian Exodus From Galilee 1948. Beirut: The Institute for Palestine Studies.

Peretz, David., Evan M. Wilson and Richard J. Ward. 1970. A Palestinian Enit Washington, D.C.: The Middle East Institute.
Appendix I

TERMINOLOGY

Al-Quds - This is the Arabic name for Jerusalem and actually means "the Holy".

Halil - This is the Arabic name for Hebron which is south of Jerusalem.

Haram al-Sharif - The Dome of the Rock and also used to general describe the general area (including the Al-Aqsa mosque), is located in East Jerusalem and is the second holiest sight to the muslim religion. Unfortunately, it is also called the Temple Mount and is where the second Jewish Temple was located. Therefore it is also holy to Jews. This was part of the reason that led to the massacre of Palestinians that occurred there in October 1990.

Intifada - This is the Arabic term for the uprising occurring in the Occupied Territories. Its literal translation is "the shaking off" and was chosen because the Palestinians are trying to shake off Israeli repression and occupation.

Jihad - An Islamic term and belief. It can either mean a physical battle or a spiritual and mental battle against untruth.

Khafiya - The headdress worn by Arabs. For the Palestinians it has been traditionally black and white or just plain white. However, the Jordanian khafiya which is red and white, is being worn by Palestinians in the Occupied Territories to show suppor for the intifada.

Occupied Territories - Refers to the area of land occupied by the Israelis in 1967. Even though this includes the Golan Heights (formerly belonging to the Syrians), it is used mainly to refer to the West Bank (including East Jerusalem) and Gaza Strip. - The use of this term is somewhat neuurai although its use implies that the speaker does not acknowledge Israel's right to continuing its holding.

Palestine - To use this tcrm in reference to the West Bank and Gaza, means that the speaker is in full support with the goal of an independent Palestinian state in these areas. However, it is an ambiguous term in reference to actual geographic location and can also be interpreted to mean the historical Palestine which included all of what is now Israel, plus the East Bank of the Jordan River. 
Mid-American Review of Sociology

Appendix II

METHODOLOGY

from? For Palestinians, this question is actually quite complicated and provided an insight into how they view their origins.

2) How long have they been there? The first part of the question was used the answer to question 1 is different than where his/her family

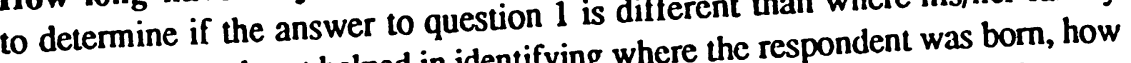
lives. The second part helped in identifying where the respondent wirst hand versus much, and what type of information the respondent would know first hand versus what s/he had been told. 3) When did your family leave Palestine? follow up questions to the last. told about this event? These questions are follow up questions than Palestine, If the respondent stated that his family lived in a country other than Palestine the first part of the question determines the family experience and the second is meant to determine what the respondent was actually told. I hoped to discover how this history was passed down. 4) Where did you grow up? Basically the respondent. This also verification question to determine the experience of the respondent. This also helped to examine the different attitudes and personal histories of Palestinians growing up in different Arab countries.

5) How long have you been in the U.S.; Kansas? Again, this question was used to determine the background and experience of the respondent. come here to the U.S.; Kansas? Originally, this Why did you come here to the U.S., Kansas? came to the U.S. but question was meant to look at the reasons the reved the workings and importance through the course of the interviews it also revealed

of the family network to Palesunians in Diasporat th 7) How do you feel about being here? discover whether the respondent had reely che course of the motivation was for doing so. This also proved, during the ciaspora.

interviews, enlightening on the family processes involved in Diaspora. 8) How would you describe yourself? Originally, this ques, whether first meant to examine how Palestinians express their ties and grew up. In actuality, to Palestine or to family, tribe, or the country where they grew up. In action in every this proved a troublesome question. I had to restate the question in every interview and as a consequence it became more of a leadir some of its value.

9) What was your first recollection of being a Palestinian? In question. I fully expected outside forces to have an active role in this self-awareness process but this was not the case. Again, the family played an important role in socializing and politicizing, so that this process tumed out to be a positive one. There were negative experiences that served as reinforcement of their Palestinian origins.

10) Is it important to you to maintain your Palestinian identity? Why or Why not? This goes back to question 8 and asks in a different way whether or not the maintenance of a Palestinian identity is important to the community in Diaspora. It also opens the possibility of them describing themselves within the context of nationhood.

11) Did you learn about your nation's (people's) history? If yes, how? I wanted to discover the process by which Palestinian history is passed down, whether through family, community, schooling, or self-education. In order for the "Palestinian nation" to continue, the learning of history becomes important and I wanted to know if and how this was continuing.

12) Are you part of a bigger local Palestinian community? If yes, is it an Arab, Islamic, or Christian community? Peoples in Diaspora tend to develop communities where ever they are located and I wanted to discover if this was also true with the Palestinians.

13) What do you do as a community? I wanted to see if the communities were political, social or familial in nature.

14) Is education important to you? Why? This question is directed specifically at the claims of some scholars to see if it is important and why.

15) What do you hope to achieve through education? This is another way of asking why education is important but gives a little more room for discussion of goals as an individual and as a nation.

16) There are some scholars who say that there was no Palestinian nation until the dispersion in 1948, that it was this expulsion that created and unified the Palestinians as a nation. How do you view this? What have you been told about this expulsion? This again is directed at the current scholarship. The second half of the question is a restatement of question \#2 for verification purposes. I had interesting reactions to this question which I will discuss in the interview section.

17) Where were you during the 1967 war? What were your feelings during and after the war? (If not born yet) What have you been told about this war? 1967 was the sccond dispersion of the Palestinian people and began a new phase in Palestinian history because those who had escaped to Egypt and Jordan after 1948 and stayed after 1967 became occupied people. I wanted to know how this history had been passed down or how it was experienced by those living through it whether in Diaspora or within the West Bank and Gaza. 
18) Do you consider the Palestine Liberation Organization 18) Do you consational representative? 19) (PLO) and Yasser Arafat to be your national Congress your Do you consider the Palestinian do yes, what do they do for you? These legitimate government? If yes, what do thestinian nationhood and also two questions go back again to the issue of Palestinian nationhe questions are aimed address for the first time, Palestinian statehood. they are adequately and fairly discovering whether the Palestinian people feel they are and how they view the represented by what their leadershi

Palestinian government-in-exile. 20) During the Gulf War, did Arafats ar his leadership? Of your Hussein change your perception of situation? This question deals with a specifestinians. I was also interested if addressing leadership representation of the Palestinians. I wecause they were in this individually, Palestinians felt threa

country and its reaction to Arafal. 21) A great deal has been written about the intifada from inside Palestine/Occupied Territories, how do you feel about the intifada? I wanted to find out if Palestinians in Diaspora fell connected a part of this movement and how they viewed it from the outside. I also warly occurring in the know what they knew or had been told about what was actually occe ind in others Occupied Territories. In some interviews I used the

used Occupied Territory. Each has a differcnt barticipate in the up 22) Do you think the Palestinians should participate in the changed 22) Deace talks? Why or why not? This question had commenced (it fairly early on. I only asked it once before the peace conference contion was then moved a lot more quickly than anyone anticipated). The questinian participation changed to: What is your opinion of the Palequately represented? in the peace talks? Do you feel you were adequately not. Also, there I wanted to know if they viewed the peace talks posip whether or not to attend had been disagreement within the Palestinian leadership whethation by the Israeli because of all the stipulations placed on the Palestinians viewed the decision by government. I wanted to know how the Palestinians vint question since the leadership to attend anyway. This is an in the delegation and the right of Palestinians in Diaspora were not represent.

return is a big question in any settement for the future? What do you think the 23) What are your hopes for the fut to get at both future will bring? This two-fold question was me Palestinian nation with or personal hopes and what th without the peace talks.
Richard D. Alba. Ethnic Identity: The Transformation of White America. New Haven and London: Yale University Press, 1990. xvi + 374 pages.

Richard Alba is interested in discovering whether ethnicity is still a salient feature of American life or if European-Americans are doomed to become "unhyphenated Americans." Regardless, Alba is sure that a fundamental transformation of ethnic identity is taking place among white Americans. Alba uses survey data from a random sample of residents in the core counties of the Albany-Schenectady-Troy metropolitan area (the "Capital Region") of New York. 524 randomly chosen respondents were interviewed concerning their ethnic ancestries, identification with their ethnic origins, ethnically related experiences, and social relationships and activities. Ethnic groups surveyed, in order of size, were: English, German, Irish, French, French Canadian, Italian, Scots, Dutch, Polish, and Native Americans. More respondents were third generation immigrants (40\%) than any other category.

The study found that the majority of white Americans still define themselves in ethnic terms. Alba notes that there are discrepancies between the ancestries reported by respondents and their ethnic identities. He hypothesizes that this is due, in part, to the complex interplay between personal ethnic identities and collective or aggregate ethnicity. Alba also suggests that it reflects differences between "objective" and "subjective" realities (ethnic identity being a subjective response to actual ancestry). Responses seemed to indicate a longterm decline in the role of ethnic identities among whites due to complex ancestry, distance from original immigration, and uncertainty about ethnic background. However, Alba noted the salience of ethnicity by the highly educated, and hypothesizes that ethnic identity becomes a form of "cultural capital."

Alba focuses on food, language, and customs as forms of cultural expressions. Few respondents still spoke their mother tongue, while consumption of ethnic foods was quite frequent. Women often cooked not only the ethnic food of their family, but the ethnic food of their husband's family as well (even when he was of a different ethnic background than she). Nevertheless, Alba questions whether food is enough to maintain ethnic identity:

it is difficult to see the cultural expressions of identity as more than a fragile and thin layer alloyed to a larger body of common American culture, with its complex class and place variants (p. 121).

Alba's concern is that ethnic identity cannot survive without social structures to sustain it. Women, (due to their greater involvement in the family), the highly educated, and young adults are more likely than others to engage in ethnic experiences, but is it only a matter of "an ethnicity of last resort" as Gans would say? 